Enkät till Dig som går eller cyklar hela vägen till arbets-/studieplatsen

\title{
Allmänna frågor
}

1. Är Du kvinna eller man?

2. Vilket år föddes Du?

3. Hur mycket väger Du? Svara i hela kilo

4. Hur lång är Du?

5. Är Du: förvärvsarbetande? frivilligarbetande? studerande? sysselsatt med annat?, ange vad: $\square$ Kvinna $\square$ Man

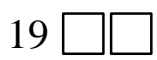

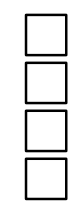

6. Har Du tillgång till dusch på arbets-/studieplatsen?

$\square$ Ja, på ett smidigt sätt $\square$ Ja, men inte på ett smidigt sätt $\square$ Nej $\square$ Vet ej

Du som går hela vägen till arbets-/studieplatsen, men aldrig cyklar dit kan gå direkt till fråga 18 på sidan 5. 
7. Vilken är din vanligaste färdväg till och från arbets-/studieplatsen? Markera på den karta du fått. Följ bifogat instruktionsbrev.

8. Uppskatta hur lång din färdväg är. Ange ungefärligt avstånd i kilometer, gärna med en decimal (t.ex. 600 meter $=0,6 \mathrm{~km}$ ).

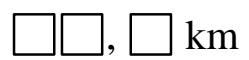

9. Hur lång tid tar vanligtvis cykelturen från bostaden till arbets-/studieplatsen? Ta tid på färden en vanlig dag då du inte gör ärenden på vägen.

$\square$ Timmar $\square \square$ Minuter

10. Hur lång tid tar vanligtvis cykelturen från arbets-/studieplatsen till bostaden? Ta tid på färden en vanlig dag då du inte gör ärenden på vägen.

$\square$ Timmar $\square \square$ Minuter

11. Hur ansträngande i genomsnitt upplever du att cykelturen till arbets/studieplatsen vanligtvis är? Sätt ett kryss i varje kolumn vid någon siffra i skalan 6-20.

Från bostaden till arbets-/studieplatsen

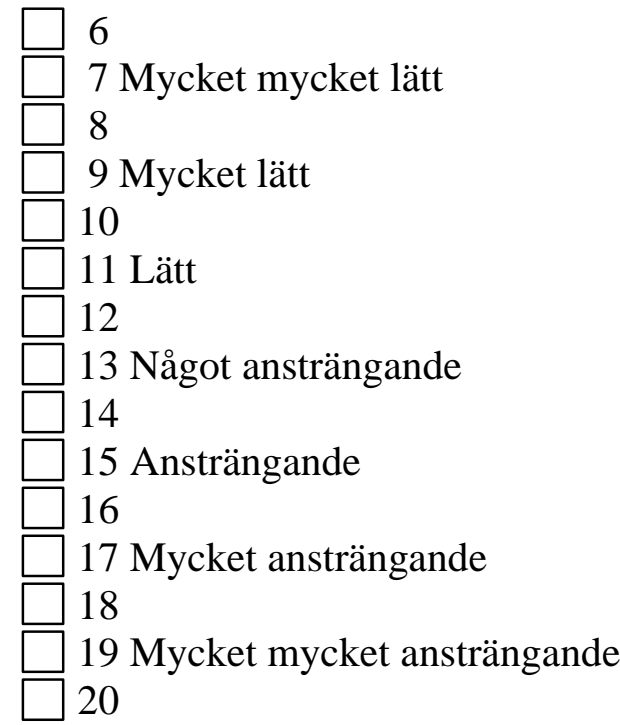

Från arbets-/studieplatsen till bostaden

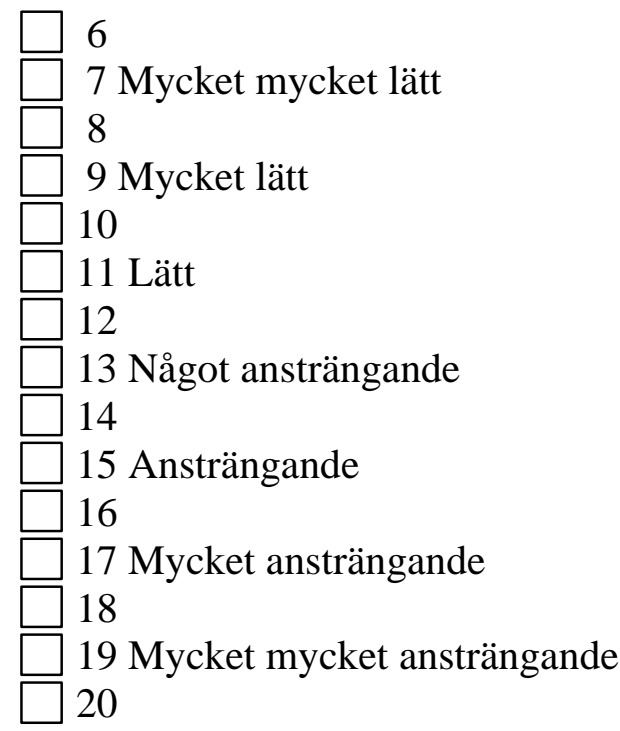


12. Cyklar du vanligtvis till och hem från arbets-/studieplatsen under samma dag?

Det vill säga du låter inte cykeln stå kvar på arbets-/studieplatsen.
$\square \mathrm{Ja}$
$\square \mathrm{Nej}$
Vet ej

Om du svarat Nej ange gärna varför:

Nu kommer en fråga som tillsammans med de färdvägar som du ritar in på kartan kommer att ge en värdefull bild av din fysiska aktivitet och även av möjliga hälsoeffekter av cyklingen.

13. Hur många cykelturer (se instruktion nedan) gör du mellan bostaden och arbets/studieplatsen i medeltal per vecka under olika månader? Sätt ett kryss för varje månad.

Så här fyller du i dina svar:

- Om du cyklar till och från arbets-/studieplatsen 5 dagar i veckan under hela månaden blir antalet cykelturer i medeltal 10 per vecka.

- Om du istället är ledig halva månaden blir antalet cykelturer i medeltal 5 per vecka under den månaden.

- Om du har semester hela månaden blir antalet cykelturer 0 .

- Om du i medeltal gör färre än 1 cykeltur i veckan men sammanlagt fler än 0 ska du fylla i rutan för $<1$.

- Om du cyklar till och/eller från arbets-/studieplatsen oregelbundet och vid ett fåtal tillfällen över året samt är osäker på vilka månader som du gör det kryssar du i rutan "Annat alternativ".

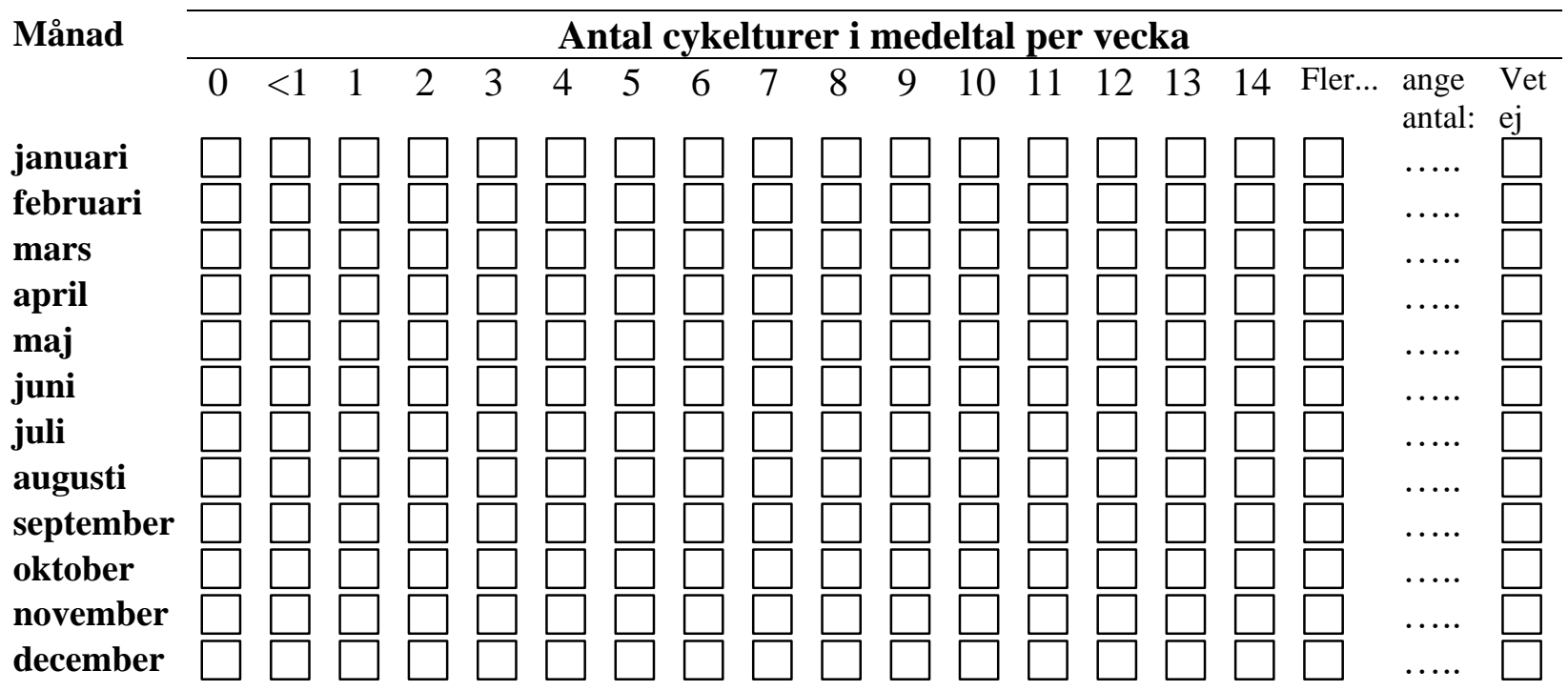

\section{Annat alternativ}


14. Hur många gånger behöver du vanligtvis stanna för rött ljus under färden till arbets-/studieplatsen? Räkna gärna antalet stopp du gör under en vanlig dag.

Stannar ej

Stannar. Ange antal stopp:
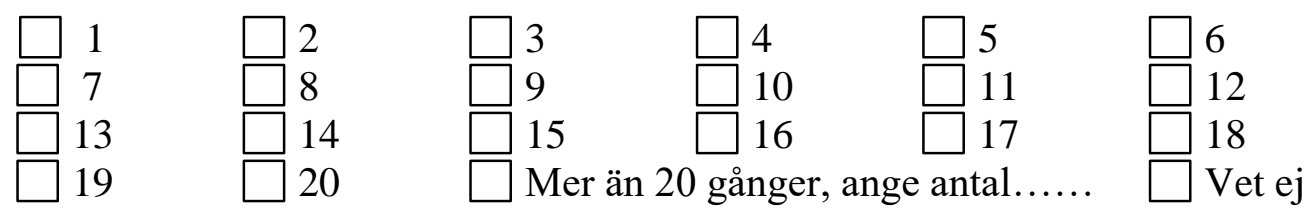

15. Blir du svettig när du cyklar till arbets-/studieplatsen?
Nej, aldrig
Ja, 1-25\% av gångerna
Ja, 26-50 \% av gångerna
$\mathrm{Ja}, 51-75 \%$ av gångerna
Ja, 76-100 \% av gångerna
Vet ej

16. Brukar du duscha efter cykelturen till arbets-/studieplatsen?
Nej, aldrig
Ja, $1-25 \%$ av gångerna
$\mathrm{Ja}, 26-50 \%$ av gångerna
$\mathrm{Ja}, 51-75 \%$ av gångerna
Ja, 76-100 \% av gångerna
Vet ej

\section{Fråga om din cykel}

17. Vilken typ av cykel använder du på cykelturen till arbets-/studieplatsen?

Oväxlad cykel

Växlad cykel (2- 4 växlar)

Växlad cykel (5 växlar eller fler)

Vet ej

Fortsätt med nästa fråga om du under det senaste året vid något tillfälle gått hela vägen till din arbets-/studieplats. Fortsätt annars med fråga 28 på sidan 8. 
18. Vilken är din vanligaste färdväg till och från arbets-/studieplatsen? Markera på den karta du fått. Följ bifogat instruktionsbrev.

19. Uppskatta hur lång din färdväg är. Ange ungefärligt avstånd i kilometer, gärna med en decimal (t.ex. 600 meter $=0,6 \mathrm{~km}$ )

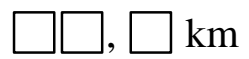

20. Hur lång tid tar vanligtvis gångturen från bostaden till arbets-/studieplatsen? Ta tid på färden en vanlig dag då du inte gör ärenden på vägen.

$\square$ Timmar $\square \square$ Minuter

21. Hur lång tid tar vanligtvis gångturen från arbets-/studieplatsen till bostaden? Ta tid på färden en vanlig dag då du inte gör ärenden på vägen.

$\square$ Timmar $\square \square$ Minuter

22. Hur ansträngande $i$ genomsnitt upplever du att gångturen till arbets/studieplatsen vanligtvis är? Sätt ett kryss i varje kolumn vid någon siffra i skalan 6-20.

$\underline{\text { Från bostaden till arbets-/studieplatsen }}$

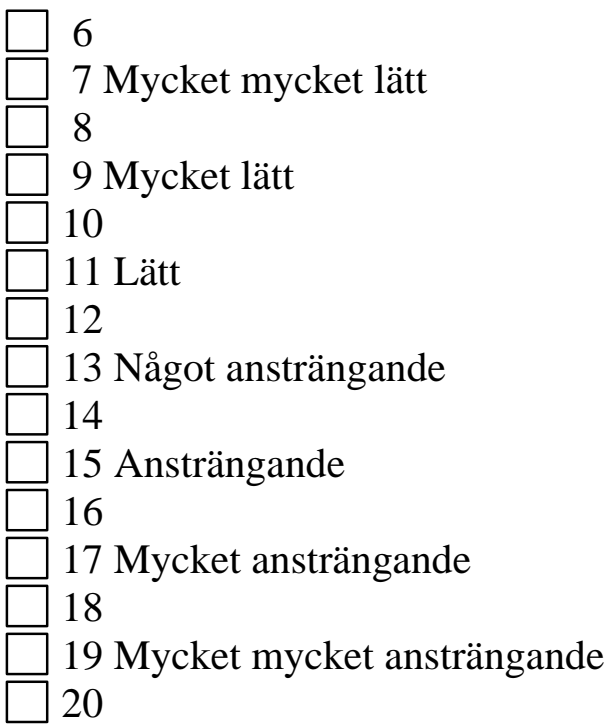

Från arbets-/studieplatsen till bostaden

$\square$
$\square$
$\square$
$\square$
8
$\square$
9 Mycket mycket lätt
10
$\square 11$ Lätt
$\square 12$
$\square 13$ Något ansträngande
$\square 14$
$\square 15$ Ansträngande
$\square 16$
$\square 17$ Mycket ansträngande
$\square 18$
$\square 19$ Mycket mycket ansträngande
$\square 20$


23. Går du vanligtvis till och hem från arbets-/studieplatsen under samma dag?

$\square$ Ja $\quad \square$ Nej $\quad \square$ Vet ej

Om du svarat Nej ange gärna varför:

Nu kommer en fråga som tillsammans med de färdvägar som du ritar in på kartan kommer att ge en värdefull bild av din fysiska aktivitet och även av möjliga hälsoeffekter av gåendet.

24. Hur många gångturer (se instruktion nedan) gör du mellan bostaden och arbets/studieplatsen i medeltal per vecka under varje månad? Sätt ett kryss för varje månad.

Så här fyller du i dina svar:

- Om du går till och från arbets-/studieplatsen 5 dagar i veckan under hela månaden blir antalet gångturer i medeltal 10 per vecka.

- Om du istället är ledig halva månaden blir antalet gångturer i medeltal 5 per vecka under den månaden.

- Om du har semester hela månaden blir antalet gångturer 0.

- Om du i medeltal gör färre än 1 gångtur i veckan men sammanlagt fler än 0 ska du fylla i rutan för $<1$.

- Om du går till och/eller från arbets-/studieplatsen oregelbundet och vid ett fåtal tillfällen över året samt är osäker på vilka månader som du gör det kryssar du i rutan "Annat alternativ".

\begin{tabular}{|c|c|c|c|c|c|c|c|c|c|c|c|c|c|c|c|c|c|c|}
\hline \multirow[t]{2}{*}{ Månad } & \multicolumn{18}{|c|}{ Antal gångturer i medeltal per vecka } \\
\hline & $0<1$ & 1 & 2 & 3 & 4 & 5 & 6 & 7 & 8 & 9 & 10 & 11 & 12 & 13 & 14 & Fler.. & $\begin{array}{l}\text { ange } \\
\text { antal: }\end{array}$ & $\begin{array}{l}\text { Vet } \\
\text { ei }\end{array}$ \\
\hline januari & & & & & & & & & & & & & & & & & ....... & \\
\hline februari & & & & & & & & & & & & & & & & & ...... & \\
\hline mars & & & & & & & & & & & & & & & & & ...... & \\
\hline april & & & & & & & & & & & & & & & & & ...... & \\
\hline maj & & & & & & & & & & & & & & & & & ...... & \\
\hline juni & & & & & & & & & & & 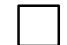 & & & & 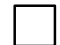 & & $\ldots \ldots$ & + \\
\hline juli & & & & & & & & & & & & & & & & & ...... & \\
\hline augusti & & & & & & & & & & & & & & & & & ...... & \\
\hline september & & & & & & & & & & & & & & & & & ...... & \\
\hline oktober & 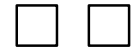 & 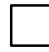 & 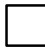 & & 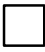 & & & & & & 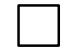 & 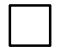 & & & 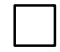 & $\square$ & ...... & $\square$ \\
\hline november & & & 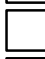 & & & & & & & & & & & & & & ...... & $\square$ \\
\hline december & L & L & & & & & & & & & & & & & & 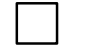 & & $\square$ \\
\hline
\end{tabular}

Annat alternativ 
25. Hur många gånger behöver du vanligtvis stanna för rött ljus under färden till arbets-/studieplatsen? Räkna gärna antalet stopp du gör under en vanlig dag.

Stannar ej

Stannar. Ange antal stopp:

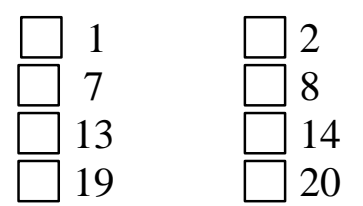

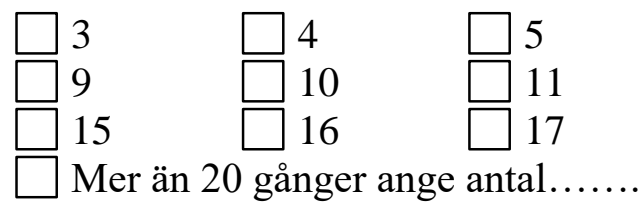

$\square 6$
$\square 12$
$\square 18$
$\square$ Vet ej

26. Blir du svettig när du går till arbets-/studieplatsen?
$\square$ Nej, aldrig
$\mathrm{Ja}, 1-25 \%$ av gångerna
$\mathrm{Ja}, 26-50 \%$ av gångerna
$\mathrm{Ja}, 51-75 \%$ av gångerna
$\mathrm{Ja}, 76-100 \%$ av gångerna
Vet ej

27. Brukar du duscha efter gångturen till arbets-/studieplatsen?

$\square$ Nej, aldrig

$\square \mathrm{Ja}, 1-25 \%$ av gångerna

$\mathrm{Ja}, 26-50 \%$ av gångerna

$\square \mathrm{Ja}, 51-75 \%$ av gångerna

$\square \mathrm{Ja}, 76-100 \%$ av gångerna

$\square$ Vet ej 
28. Hur fysiskt ansträngande har ditt dagliga arbete eller din dagliga sysselsättning (ej fritid) varit under de senaste 12 månaderna?

$\square$ Mycket lätt, övervägande stillasittande

$\square$ Lätt fysiskt arbete men där jag rör mig en hel del (t.ex. lätt industriarbete, affärsbiträde, lärare)

Ganska fysiskt ansträngande arbete (t.ex. lokalvårdare, brevbärare, sjukvårdsbiträde)

Mycket fysiskt ansträngande arbete (tungt kroppsarbete, t.ex. cykelbud, tyngre skogsarbete eller byggnadsarbete)

29. Har du möjlighet att motionera/träna på betald arbetstid?

$\square$ Nej
$\square$ Ja, men utnyttjar det ej
$\square$ Ja, och jag utnyttjar det
$\square$ Vet ej

Om du svarat "Ja, och jag utnyttjar det" fortsätt med nästa fråga, i andra fall fortsätt till fråga 32 på sidan 10 .

30. Vilken typ av aktivitet, samt hur ofta och hur länge motionerar/tränar du vanligtvis på betald arbetstid? Använd ett medelvärde om det varierar mellan veckorna. Du kan ange flera aktiviteter.

\begin{tabular}{|c|c|c|}
\hline Aktivitet & $\begin{array}{l}\text { Antal tillfällen } \\
\text { per vecka }\end{array}$ & $\begin{array}{l}\text { Tid per } \\
\text { träningspass }\end{array}$ \\
\hline$\square$ Styrketräning & ............. gånger & .......min \\
\hline$\square$ Konditionsträning & ............... gånger & ....... min \\
\hline$\square$ Bollspel & ............. gånger & ....... min \\
\hline $\begin{array}{l}\square \text { Motionsgymnastik } \\
\text { (t.ex. aerobics/Friskis \& Svettis) }\end{array}$ & ............. gånger & .......min \\
\hline $\begin{array}{l}\square \text { Annat, } \\
\text { ange vad: }\end{array}$ & & \\
\hline (1) & $\begin{array}{l}\ldots \ldots \ldots \ldots \ldots \text { gånger } \\
\ldots \ldots \ldots \ldots \ldots \ldots \text { gånger } \\
\ldots \ldots \ldots \ldots \ldots \ldots \text { gånger }\end{array}$ & $\begin{array}{l}\ldots \ldots \ldots \min \\
\ldots \ldots \ldots \min \\
\ldots \ldots \ldots \min \end{array}$ \\
\hline
\end{tabular}


31. Med vilken genomsnittlig ansträngningsnivå motionerar/tränar du vanligtvis på betald arbetstid? Sätt endast ett kryss. Använd således ett medelvärde för de olika aktiviteterna om du utövar flera aktiviteter.

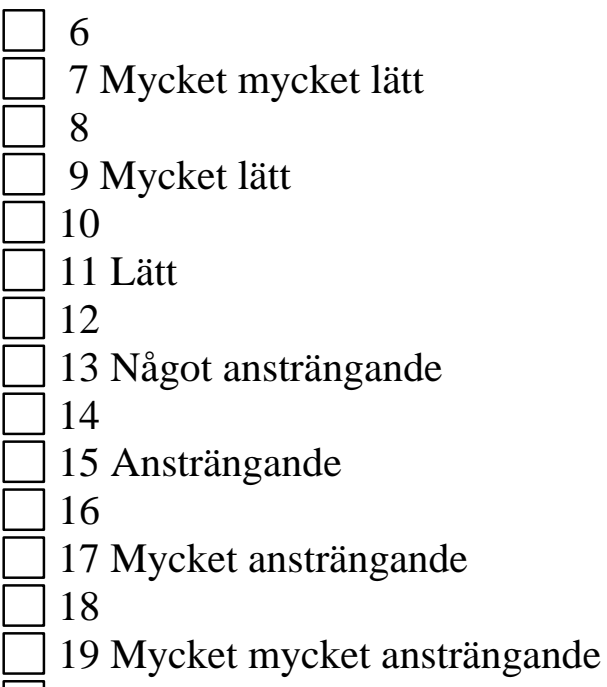


32. Hur mycket har du i allmänhet rört dig eller ansträngt dig kroppsligt på din fritid under det senaste året? OBS! Sätt kryss för alla alternativ som stämmer in på dig. Du ska inte räkna fysisk aktivitet vid arbetspendling d.v.s. att cykla och gå till arbets-/studieplatsen.

a) Har rört mig mycket litet

b) Har rört mig mycket litet men ibland tagit någon enstaka promenad eller liknande

c) Har fått "vardagsmotion" i samband med städning, att gå i trappor, trädgårdsarbete, sällskapsdans, promenad eller lättare cykelturer (bortsett från gång-/cykelturer hela vägen till arbets-/studieplatsen), att man går ut med hunden etc.

d) Har, utöver aktiviteterna i c), ägnat mig åt lättare form av motion som promenader (eller andra aktiviteter med motsvarande ansträngning) minst en gång per vecka

e) Har ägnat mig åt mer ansträngande motion som t.ex. snabba promenader, joggning, simning, motionsgymnastik eller motsvarande minst en gång per vecka

f) Har regelbundet ägnat mig åt hård träning eller tävling där den fysiska ansträngningen varit stor, t.ex. löpning och olika bollspel

Du som fyllt i svarsalternativen e) och/eller f) i fråga 32 kan fortsätta med nästa fråga. Övriga kan fortsätta med fråga 35 på nästa sida.

33. Du som fyllt i alternativ e) och/eller f) i fråga 32, vilken typ av aktiviteter, samt hur ofta och hur länge motionerar/tränar du vanligtvis? Använd ett medelvärde om det varierar mellan veckorna. Du kan ange flera aktiviteter.

\section{Aktivitet}

$\square$ Styrketräning

Konditionsträning

Bollspel

Motionsgymnastik

(t.ex. aerobics/

Friskis \& Svettis)

$\square$ Annat,

ange vad:
Kategori Tid per

\section{e) f) tillfälle}

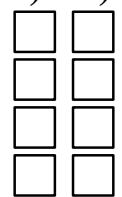

........ min

........ min

........ min

$\min$
Antal gånger Antal månader

per vecka per år

............ ...........

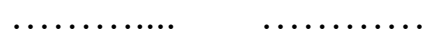

……

$\square \square \quad \begin{aligned} & \text {........min } \\ & \square \square \quad \text {...... min }\end{aligned}$ 
34. Du som fyllt i alternativ e) respektive f) i fråga 32 och 33, med vilken genomsnittlig ansträngningsnivå motionerar/tränar du vanligtvis?

Sätt endast ett kryss i respektive kolumn. Använd således ett medelvärde för de olika aktiviteterna om du utövar flera aktiviteter inom alternativ e) respektive f).

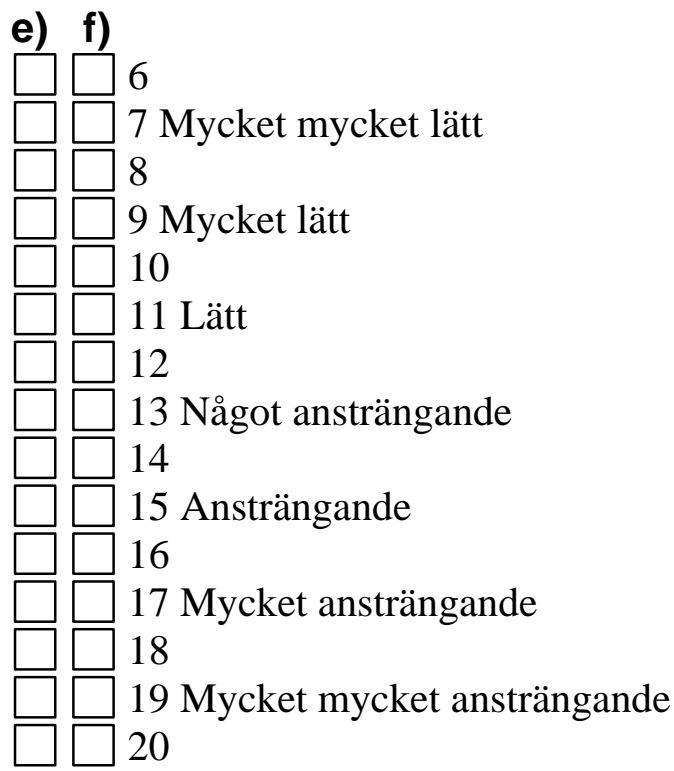

35. Är du intresserad av att delta i studiens kommande steg?

Steg 2. Enkätstudiens andra del. $\quad \square$ Ja $\quad \square$ Nej $\square$ Vet ej

Steg 3. Konditionstest och mätning av energiomsättning under färdvägen. $\quad \square$ Ja $\quad \square$ Nej $\square$ Vet ej

36. Om du har synpunkter på denna undersökning och dess frågor så skriv dem gärna här och vid behov fortsätt på baksidan.

Stort tack för hjälpen! 